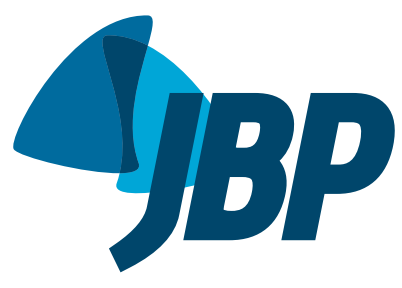

\title{
Epidemiological aspects, clinical manifestations, and prevention of pediatric tuberculosis from the perspective of the End TB Strategy
}

\author{
Anna Cristina Calçada Carvalho,,a, Claudete Aparecida Araújo Cardoso ${ }^{2, b}$, \\ Terezinha Miceli Martire ${ }^{3, c}$, Giovanni Battista Migliori ${ }^{4, d}$, Clemax Couto Sant'Anna ${ }^{5, e}$
}

1. Laboratório de Inovações em Terapias, Ensino e Bioprodutos - LITEB Instituto Oswaldo Cruz, Fundação Oswaldo Cruz, Rio de Janeiro (RJ) Brasil.

2. Departamento Materno Infantil, Faculdade de Medicina, Universidade Federal Fluminense, Niterói (RJ) Brasi

3. Faculdade de Medicina, Universidade Federal do Estado do Rio de Janeiro UniRio - Rio de Janeiro (RJ) Brasil.

4. WHO Collaborating Centre for TB and Lung Diseases, Fondazione Salvatore Maugeri, Istituto di Ricovero e Cura a Carattere Scientifico - IRCCS - Tradate Italia.

5. Departamento de Pediatria, Faculdade de Medicina, Universidade Federal do Rio de Janeiro, Rio de Janeiro (RJ) Brasil.

a. (ID) http://orcid.org/0000-0002-0128-942X

b. (ID) http://orcid.org/0000-0002-7638-6814

c. (iD http://orcid.org/0000-0002-7614-062X

d. (D) http://orcid.org/0000-0002-2597-574X

e. (D) http://orcid.org/0000-0001-8732-8065

Submitted: 14 December 2017 Accepted: 11 February 2018

\begin{abstract}
Tuberculosis continues to be a public health priority in many countries. In 2015 , tuberculosis killed 1.4 million people, including 210,000 children. Despite the recent progress made in the control of tuberculosis in Brazil, it is still one of the countries with the highest tuberculosis burdens. In 2015, there were 69,000 reported cases of tuberculosis in Brazil and tuberculosis was the cause of 4,500 deaths in the country. In 2014, the World Health Organization approved the End TB Strategy, which set a target date of 2035 for meeting its goals of reducing the tuberculosis incidence by $90 \%$ and reducing the number of tuberculosis deaths by $95 \%$. However, to achieve those goals in Brazil, there is a need for collaboration among the various sectors involved in tuberculosis control and for the prioritization of activities, including control measures targeting the most vulnerable populations. Children are highly vulnerable to tuberculosis, and there are particularities specific to pediatric patients regarding tuberculosis development (rapid progression from infection to active disease), prevention (low effectiveness of vaccination against the pulmonary forms and limited availability of preventive treatment of latent tuberculosis infection), diagnosis (a low rate of bacteriologically confirmed diagnosis), and treatment (poor availability of child-friendly anti-tuberculosis drugs). In this review, we discuss the epidemiology, clinical manifestations, and prevention of tuberculosis in childhood and adolescence, highlighting the peculiarities of active and latent tuberculosis in those age groups, in order to prompt reflection on new approaches to the management of pediatric tuberculosis within the framework of the End TB Strategy.
\end{abstract}

Keywords: Tuberculosis, pulmonary/prevention \& control; Mycobacterium tuberculosis; Lung diseases/etiology; Child; Adolescent.

Study carried out under the auspices of European Respiratory Society/LatinAmerican Thoracic Association and European Respiratory Society/Brazilian Thoracic Association collaborative projects.

\section{INTRODUCTION}

Tuberculosis is still one of the main causes of morbidity and mortality worldwide. The World Health Organization (WHO) estimates that, in 2016, there were 10.4 million new cases of tuberculosis, as well as that, in that same year, tuberculosis caused the deaths of 1.3 million non-HIV-infected individuals and 374,000 HIV-infected individuals. Also in 2016, tuberculosis was one of the ten leading causes of death worldwide, ranking above HIV/AIDS as the leading cause of death from a single infectious agent. ${ }^{(1)}$

Children are particularly vulnerable to tuberculosis. Pediatric cases of tuberculosis account for $10 \%$ of all cases of the disease. In 2015, there were an estimated 1 million new cases of childhood tuberculosis and an estimated 210,000 deaths from tuberculosis in children. ${ }^{(2)}$
Despite the advances in tuberculosis control achieved in the last decade, our country still ranks among those with the highest tuberculosis burdens. In the new WHO classification of priority countries for tuberculosis control worldwide (comprising three lists of 30 countries each), Brazil ranked 20th regarding the burden of disease and 19th regarding the tuberculosis/HIV coinfection. ${ }^{(2,3)}$ In 2015, 69,000 tuberculosis cases were reported in Brazil $(4,500$ of those cases resulting in death), 6,800 HIV-infected individuals were diagnosed with tuberculosis, and more than 1,000 individuals developed multidrug-resistant tuberculosis (MDR-TB) or extensively drug-resistant tuberculosis (XDR-TB). ${ }^{(3)}$

In 2014, the WHO approved The End TB Strategy, which is in alignment with the United Nations Sustainable Development Goals. The new strategy adopts the vision of "A world free of tuberculosis - zero deaths, disease and suffering due to tuberculosis" and has the goal of ending

Correspondence to:

Anna Cristina C. Carvalho. Laboratório de Inovações em Terapias, Ensino e Bioprodutos - LITEB - Instituto Oswaldo Cruz, Fundação Oswaldo Cruz, Avenida Brasil, 4365, Manguinhos, CEP 21040-360, Rio de Janeiro, RJ, Brasil.

Tel.: 5521 2562-1050. Mobile: 5521 99956-4638. E-mail: anna.carvalho@ioc.fiocruz.br 
the global epidemic and eliminating tuberculosis in lowincidence countries. The goals, to be met by 2035 , are a $90 \%$ reduction in the incidence rate and a $95 \%$ reduction in the number of deaths due to tuberculosis-both in comparison with the rates reported for 2015. The first translates to a reduction in the tuberculosis incidence rate to fewer than 10 cases/100,000 population, which would represent the end of tuberculosis as a public health problem and a major step forward in disease control worldwide. However, the complete elimination of tuberculosis, defined as below 1 case/100,000,000 population, is an even more ambitious goal. In order for these objectives of the End TB Strategy to be achieved, there must be effective control measures that are based on three pillars ${ }^{(3-6)}$ : integrated, patientcentered tuberculosis care and prevention; bold policies and supportive systems; and intensified research and innovation related to tuberculosis.

Given the considerations listed above, the relevance of tuberculosis at the global, regional, and national levels becomes evident. However, the importance of tuberculosis as a cause of morbidity and mortality in individuals under 15 years of age and the peculiarities of its prevention, diagnosis, and treatment in that age group have only recently gained prominence in the international scientific community. ${ }^{(7)}$ In this review, we present the main clinical and epidemiological aspects of tuberculosis in children, together with aspects related to its prevention, aiming to contribute to the discussion of interventions to be implemented in pediatric tuberculosis patients within the framework of the End TB Strategy.

\section{EPIDEMIOLOGY}

The occurrence of tuberculosis in children is closely related to the prevalence of tuberculosis among adults. The risk of developing infection with Mycobacterium tuberculosis is higher for children living in regions where there is a high prevalence of active tuberculosis, in dwellings with high population density (many people sleeping in the same room), and in buildings with poor ventilation. ${ }^{(8-10)}$

In 2016, new cases of tuberculosis notified among children accounted for $6.9 \%$ of all tuberculosis cases worldwide. In that same year, there were over a million estimated new cases of pediatric tuberculosis-550,000 (range, 340,000-760,000) among males and 490,000 (range, 300,000-680,000) among females-corresponding to $10 \%$ of all new tuberculosis cases worldwide. According to the WHO, the three regions where most pediatric tuberculosis cases are concentrated are Southeast Asia, Africa, and the Western Pacific, which respectively accounted for $35 \%, 30 \%$, and $20 \%$ of the new cases reported in 2015. (1)

It is estimated that tuberculosis caused the death of 210,000 children worldwide in 2015 , $^{(2)}$ although mathematical models indicate that the number could have reached $239,000,80 \%(191,000)$ of those deaths having occurred in children under 5 years of age in Africa and Southeast Asia. ${ }^{(11)}$ Based on those estimates, Dodd et al.(11) stated that tuberculosis might be the sixth leading cause of death in the 1- to 5-year age group, causing more deaths than do diseases such as meningitis, AIDS, measles, and whooping cough.

The mortality associated with tuberculosis among children who go untreated has been estimated to be $21.9 \%$ overall and $43.6 \%$ among those under 5 years of age. However, it has been reported that such mortality can be reduced to $0.9 \%$ when tuberculosis treatment is carried out properly. ${ }^{(12)}$ Mortality due to tuberculosis in children is underestimated, because, for many children who die from tuberculosis, the cause of death is listed as pneumonia, HIV/AIDS, meningitis, or malnutrition. ${ }^{(13,14)}$

There are no official estimates of the prevalence of latent tuberculosis infection (LTBI) among children, because there are no accurate diagnostic tests. However, in a study using mathematical modeling, ${ }^{(11)}$ it was estimated that the number of children with LTBI worldwide in 2010 was 53,000,000 (95\% CI: $41,000,000-69,000,000)$.

\section{NATURAL HISTORY OF TUBERCULOSIS IN CHILDREN}

Approximately $90 \%$ of people do not become ill after primary infection with $M$. tuberculosis, subsequently developing LTBI. ${ }^{(15-17)}$ However, children are at a higher risk of rapid progression from tuberculosis infection to active tuberculosis and more often develop the extrapulmonary or disseminated forms of the disease. The risk of active tuberculosis is highest in children under 5 years of age, and recent evidence suggests that children can become infected after only 15-20 min of exposure to $M$. tuberculosis. ${ }^{(17-20)}$ After $M$. tuberculosis infection, the disease can manifest at any time in life, depending on the balance between the pathogen and the host immunity, especially cellular immunity, although most children will develop active tuberculosis within a year after becoming infected. That is why determining the history of contact with cases of pulmonary tuberculosis (PTB) is so important and reveals the maintenance of tuberculosis transmission within the community. ${ }^{(17)}$

The differences between the pediatric and adult populations in terms of the pathophysiology and clinical features of tuberculosis make the diagnosis of the disease more challenging in the former. ${ }^{(18,21)}$ Various factors seem to influence the balance between the risk of LTBI and the progression to active tuberculosis, such factors including age, nutritional status, BCG vaccination, and immune status. ${ }^{(18,22)}$

Data regarding active surveillance in the era before tuberculosis treatment suggest that most children develop radiological signs after $M$. tuberculosis infection, including $60-80 \%$ of children under 2 years of age. However, less than $10 \%$ of those cases were reported, 
suggesting that $M$. tuberculosis infection was controlled by the host immune response in most cases. ${ }^{(22,23)}$

Pulmonary infection with $M$. tuberculosis occurs when bacilli successfully reach a terminal airway, resulting in a localized pulmonary inflammatory process called a parenchymal focus (Ghon focus). From this focus, the bacilli disseminate through the local lymphatic system to regional lymph nodes. A Ghon focus is characterized by local tuberculous lymphangitis and the involvement of regional lymph nodes. This combination is known as the primary complex. From the regional lymph nodes, the bacilli enter the systemic circulation directly or via the lymph duct. This occult hematogenous dissemination occurs before an appropriate immune response is able to prevent the development of active tuberculosis. After dissemination, the bacilli can survive within the target organs for long periods. The future course of active tuberculosis depends on the dynamic balance between the host immunity and the pathogen. ${ }^{(24)}$

In children under 2 years of age, primary tuberculosis infection frequently progresses to severe disease, without significant prior symptoms, usually in the first 12 months after contact with active tuberculosis cases. In children 2-10 years of age, primary infection rarely progresses to severe disease; when that does occur, it is accompanied by significant clinical symptoms. In children over 10 years of age, primary infection usually evolves to adult-type active tuberculosis. Effective early intervention in this age group will reduce the possibility of cavitary disease and transmission of the disease to the community. The disease has been observed to behave the same way in immunocompromised children as in children with immature immunity (those under 2 years of age). ${ }^{(18,24)}$

The evolution of tuberculosis after pulmonary infection in childhood includes a number of phases ${ }^{(24)}$ :

- Phase 1 begins 3 to 8 weeks after the primary infection. At the end of the initial asymptomatic period, the patient may present hypersensitivity reactions, such as fever, erythema nodosum, a positive response to the tuberculin skin test (TST), and development of the primary complex, which can be seen on a chest X-ray.

- Phase 2 begins 1-3 months after the primary infection, following the occult hematogenous dissemination that occurs during the incubation. This is the period of greatest risk for the development of tuberculous meningitis and miliary tuberculosis in small children, although these manifestations of tuberculosis may occur at any time after hematogenous dissemination.

- Phase 3 begins 3-7 months after the primary infection. During this phase, there can be pleural effusion in children over 5 years of age and bronchial disease in children under 5 years of age.

- Phase 4 lasts from the end of phase 3 until the calcification of the primary complex, which occurs 1-3 years after the primary infection. In phase 4, osteoarticular tuberculosis can occur in children under 5 years of age and adult-type active tuberculosis can develop in adolescents. In general, the risk of disease progression is minimal when calcification occurs. However, adult-type active tuberculosis, a delayed manifestation following the primary infection, develops after the calcification is present.

- Phase 5 begins after the calcification is concluded, more than 3 years after the primary infection. This phase represents the period of late tuberculosis manifestations, including reactivation of pulmonary tuberculosis.

\section{CLINICAL MANIFESTATIONS OF TUBERCULOSIS IN CHILDHOOD}

From the clinical perspective, childhood tuberculosis presents nonspecific signs and symptoms that worsen with time, and some children with active PTB can be asymptomatic, in which case active PTB can be clinically mistaken for LTBI. ${ }^{(25)}$ The main symptoms of pediatric tuberculosis include fatigue, loss of appetite, night sweats, weakness, weight loss, and evening fever. When the disease reaches the lungs, the child can present chest pain and cough (productive or nonproductive), which can, in rare cases, be accompanied by hemoptysis. Other signs and symptoms include fever (moderate, persistent for 15 days or more, and often arising in the evening), weight loss, anorexia, hemoptysis, pallor, lymphadenopathy, and hepatosplenomegaly. Persistent cough (productive or not) is the main symptom of the pulmonary form of the disease, which is the most common form of pediatric tuberculosis. ${ }^{(16,26)}$ Erythema nodosum, keratoconjunctivitis, and joint pain can also occur. It is noteworthy that hemoptysis can occur in adolescence but is rare in childhood. (27)

Tuberculosis can affect organs other than the lungs; approximately $20 \%$ of tuberculosis cases in children have extrapulmonary manifestations. ${ }^{(26)}$ In such cases, the symptoms vary according to the organs affected and can occur in the lymph nodes, kidneys, bones, and meninges, among other sites. One of the most serious forms of the disease is miliary tuberculosis, resulting from the hematogenous dissemination of $M$. tuberculosis, which increases the risk of meningitis. ${ }^{(16)}$

In HIV-infected patients, the clinical presentation of tuberculosis is influenced by the degree of immunosuppression and, in general, the diagnostic investigation in patients with tuberculosis/HIV coinfection is similar to that employed for the general population. ${ }^{(28,29)}$ In addition, because of the greater frequency of extrapulmonary and disseminated forms in HIV-infected children, an appropriate diagnostic investigation includes invasive procedures to obtain clinical specimens (such as those of pleural fluid and cerebrospinal fluid) or biopsy samples from solid organs (such as lymph nodes and the pleura). (29)

\section{DIAGNOSING TUBERCULOSIS IN CHILDREN AND ADOLESCENTS}

The diagnosis of tuberculosis in childhood continues to be a challenge. The main international consensus statement on childhood tuberculosis, published by the WHO, emphasizes this notion and states that the 
clinical, radiological, and epidemiological features are the most indicative of active tuberculosis in childhood. Therefore, the approach to diagnosing tuberculosis in children is based on the following ${ }^{(17)}$ : careful clinical history taking (including the history of contact with tuberculosis cases and of symptoms consistent with the disease); a thorough clinical examination, with special attention to aspects of childhood development; the TST result; chest X-ray findings (when available); bacteriological confirmation whenever possible; specific investigation of the organ involved in suspected cases of pulmonary and extrapulmonary tuberculosis; and $\mathrm{HIV}$ testing. The WHO consensus statement also highlights the importance of seeking bacteriological or molecular confirmation with the molecular test for M. tuberculosis and for resistance to rifampin (Xpert MTB/RIF) and does not recommend the so-called "therapeutic test"; that is, the attempt to establish a diagnosis by applying the treatment for tuberculosis and awaiting an improvement in the clinical status of the patient. ${ }^{(17)}$

In children living with HIV/AIDS, tuberculosis should be investigated at all routine clinical visits by inquiring about the existence of the four main symptoms: fever, cough, night sweats, and weight loss. The presence of any of those symptoms is suggestive of active tuberculosis and indicates the need for a more detailed investigation. ${ }^{(30)}$

\section{Radiological aspects of tuberculosis in children and adolescents}

Some of the radiological aspects of tuberculosis in childhood are shown in Chart 1 . The radiological aspects most commonly associated with PTB fall into two categories: those observed in patients $<10$ years of age; and those observed in patients $10-18$ years of age. In children under 10 years of age, there is a predominance of images consistent with primary tuberculosis or the primary complex. In such patients, the primary complex is evolving and the manifestations usually occur within the first 5 years after primary infection. Such manifestations include hilar lymphadenopathy, miliary images (diffuse micronodular or nodular infiltrates, usually bilateral), and characteristics of chronic or slowly evolving pneumonia-also known as expansive pneumonia. ${ }^{(31)}$ In patients $10-18$ years of age, the radiological aspect is one of post-primary tuberculosis (i.e., adult type tuberculosis). ${ }^{(31)}$ In such patients, the images are predominantly in the upper third or in the superior segment of the lower lobe of both lungs, often showing cavitations. ${ }^{(31)}$

\section{Microbiological diagnosis}

The confirmation of a diagnosis of tuberculosis by means of bacteriological testing is, in general, difficult to achieve in younger children but viable in those $\geq$ 10 years of age, who typically develop bacteriological PTB. Most children who develop primary tuberculosis are sputum smear-negative or produce paucibacillary specimens. Children under 8 years of age rarely produce sputum, and the diagnosis of tuberculosis in such children is made without bacteriological confirmation in $80 \%$ of cases. For children who cannot expectorate, it is recommended that samples be collected through gastric lavage if possible. ${ }^{(17)}$ However, the use (direct examination and culture) of induced sputum samples in children has proven to be more sensitive than is gastric lavage and is usually well accepted. ${ }^{(32,33)}$

In practice, the conventional Ziehl-Neelsen method is still used for direct staining for AFB. However, the method has low (10-15\%) sensitivity for specimens with a concentration below $5 \times 10^{3}$ bacilli/mL, which explains the negative results in children who produce paucibacillary specimens. ${ }^{(17)}$ The alternative method would be fluorescent light-emitting diode microscopy, which, in most studies, has higher sensitivity and specificity than does Ziehl-Neelsen staining. Likewise, the culture can be carried out on conventional Löwenstein-Jensen medium or, more recently, in Middlebrook 7H9 liquid medium, the latter having the advantages of more rapid $M$. tuberculosis growth and higher sensitivity for paucibacillary specimens (including blood samples). Middlebrook 7H9 has become the culture medium of choice for use in automated methods (Chart 2). Among such methods, the most well-known is the use of the BACTEC Mycobacteria Growth Indicator Tube 960 system, which is a fully automated, nonradiometric method with an average detection time of 7 days. ${ }^{(28)}$

Chart 1. Most common clinical and radiological aspects of pulmonary tuberculosis in children and adolescents.

\begin{tabular}{|c|c|c|c|c|c|}
\hline \multirow[t]{2}{*}{ Aspect } & \multicolumn{5}{|c|}{ Pediatric patients } \\
\hline & \multicolumn{3}{|c|}{$<10$ years of age } & \multicolumn{2}{|c|}{$10-18$ years of age } \\
\hline $\begin{array}{l}\text { Signs and } \\
\text { symptoms }\end{array}$ & \multicolumn{3}{|c|}{$\begin{array}{l}\text { Persistent fever, weight loss, } \\
\text { cough, and irritability }\end{array}$} & \multicolumn{2}{|c|}{$\begin{array}{l}\text { Persistent fever, adynamia, and } \\
\text { expectoration (bloody sputum) }\end{array}$} \\
\hline \multicolumn{6}{|l|}{ Chest X-ray } \\
\hline Finding & $\begin{array}{c}\text { Right hilar } \\
\text { lymphadenopathy }\end{array}$ & Chronic pneumonia & Miliary pattern & $\begin{array}{l}\text { Pulmonary } \\
\text { cavitations }\end{array}$ & Pleural effusion \\
\hline
\end{tabular}




\section{Molecular diagnosis}

The molecular diagnosis of tuberculosis involves genotypic tests based on the amplification of nucleic acids (nucleic acid amplification tests). Such tests include line probe assays and the Xpert MTB/RIF assay. All of these methods offer the great advantage of faster laboratory results and identification of resistance to drugs such as rifampin and isoniazid, as well as high sensitivity and specificity (Chart 2).

The Xpert MTB/RIF assay has been available in several cities in Brazil since 2014. It is a nucleic acid amplification test that employs the technique of real-time polymerase chain reaction on the GeneXpert platform. In Brazil, it is known as the rapid molecular tuberculosis test. The Xpert MTB/RIF assay facilitates the identification of mycobacterial DNA and reduces the risk of cross-reactivity during the amplification of the DNA. Its result can be obtained in the laboratory in approximately $2 \mathrm{~h}$, allowing the identification of $M$. tuberculosis and the detection of rifampin-resistant strains. ${ }^{(34)}$ The incorporation of the molecular diagnosis of tuberculosis has also been recommended for use in children since 2013. ${ }^{(35)}$ The use of the Xpert MTB/RIF assay in pediatric tuberculosis is still limited, because its performance is best in bacteriologically confirmed tuberculosis, which accounts for only a minority of cases in children. ${ }^{(36)}$

In a retrospective study on the use of the Xpert MTB/RIF assay at primary health care clinics in the city of Rio de Janeiro, the Xpert MTB/RIF assay result was positive (detectable levels of $M$. tuberculosis) in $131(16 \%)$ of 852 cases of suspected tuberculosis in adolescents, rifampin-resistant strains being identified in $3(2 \%)$. $^{(37)}$ A part of the samples obtained from cases detected by the Xpert MTB/RIF assay were submitted to drug susceptibility testing and $17 \%$ were found to be resistant to drugs other than rifampin. ${ }^{(37)}$

Scoring system for tuberculosis diagnosis in childhood

In 2002, the Brazilian National Ministry of Health (NMH) proposed a new scoring system for the diagnosis of intrathoracic tuberculosis (PTB), ${ }^{(15)}$ which has already been validated, in HIV-infected and non-HIV-infected children, ${ }^{(38,39)}$ and tested in other countries, ${ }^{(40,41)}$ showing high accuracy. Recently, a group of authors ${ }^{(42)}$ employed a variety of diagnostic systems, including that proposed by the $\mathrm{NMH}$, to study a cohort of 121 HIV-infected children and adolescents. The NMH system has been found to produce few false-positive results and to be useful as a screening test in such patients (Chart 3). However, the bacteriological diagnosis of active tuberculosis should be carried out whenever possible, because, among other advantages, it allows the identification of $M$. tuberculosis and of the profile of susceptibility to anti-tuberculosis drugs, which is particularly relevant given the increasing number of cases of MDR-TB and XDR-TB. ${ }^{(35)}$

\section{New diagnostic methods}

The recent introduction of a new version of the Xpert MTB/RIF assay, known as the Xpert MTB/RIF Ultra assay, could improve the accuracy of the diagnosis childhood tuberculosis, because its sensitivity is superior to that of the conventional Xpert MTB/RIF assay for paucibacillary samples. The frequency of positive results in respiratory and cerebrospinal fluid samples obtained from children has been found to be greater with the use of the Xpert MTB/RIF Ultra assay than with that of the Xpert MTB/RIF assay. ${ }^{(1)}$

The string test is a new diagnostic method that has been used for the diagnosis of tuberculosis in children. The patient swallows a capsule containing a thin string, which unravels in the stomach and is coated with gastrointestinal secretion. After some time, the string is removed and the material is sent to the laboratory so it can be processed by bacteriological or molecular methods. The string test resembles conventional gastric lavage but is less invasive. However, there have been few studies of the use of the string test in diagnosing tuberculosis in children. In a study conducted by Nansumba et al., ${ }^{(43)}$ the results were similar to those obtained from induced sputum.

Chart 2. Bacteriological and molecular methods for the diagnosis of childhood tuberculosis.

\begin{tabular}{|c|c|c|c|}
\hline Method & Time to results & Sensitivity & Specificity \\
\hline \multicolumn{4}{|l|}{ Microscopy } \\
\hline Ziehl-Neelsen staining & Same day & $32-94 \%$ & $50-99 \%$ \\
\hline Fluorescent LED & Same day & $52-97 \%$ & $94-100 \%$ \\
\hline \multicolumn{4}{|l|}{ Culture } \\
\hline Liquid media with susceptibility testing & 10-21 days & $\begin{array}{c}89 \%(\mathrm{AFB}+) \\
73 \%(\mathrm{AFB}-\text { and culture+) }\end{array}$ & $>99 \%$ \\
\hline \multicolumn{4}{|l|}{ Molecular technique (NAATs) } \\
\hline Xpert MTB/RIF assay & Same day & $\begin{array}{c}98 \%(\mathrm{AFB}+) ; 67 \% \text { (AFB-) } \\
\text { 95\%, RIF-resistant }\end{array}$ & $\begin{array}{c}\text { 99\% (AFB-) } \\
\text { 98\%, RIF-resistant }\end{array}$ \\
\hline LPA (1 line) [INH and RIF] & 1-2 days & $98 \%, \mathrm{RIF} ; 84 \%$, INH & $99 \%$ \\
\hline LPA (2 lines) [Fluo; Injet] & 1-2 days & $86-87 \%$ & $99 \%$ \\
\hline LAMP & Same day & $76-80 \%$ & $97-99 \%$ \\
\hline
\end{tabular}

LED: light-emitting diode; NAATs: nucleic acid amplification tests; Xpert MTB/RIF assay: molecular test for $M$. tuberculosis and for resistance to rifampin; RIF: rifampin; INH: isoniazid; LPA: line probe assay; Fluo: fluoroquinolones; Injet: second-line injectable drugs; and LAMP: loop-mediated isothermal amplification. Source: Pai et al. ${ }^{(45)}$ 
Chart 3. Diagnosis of pulmonary tuberculosis using the Brazilian National Ministry of Health scoring system in children and adolescents who have tested negative on sputum smear microscopy. ${ }^{a}$

\begin{tabular}{|c|c|c|c|c|}
\hline Clinical findings & Chest $X$-ray findings & $\begin{array}{c}\text { History of } \\
\text { contact with an } \\
\text { adult pulmonary } \\
\text { tuberculosis case }\end{array}$ & TST & Nutritional status \\
\hline $\begin{array}{l}\text { Fever or fatigue, } \\
\text { productive cough, weight } \\
\text { loss, night sweats for }>2 \\
\text { weeks despite nonspecific } \\
\text { antibiotic use }\end{array}$ & $\begin{array}{l}\text { Adenomegaly or miliary } \\
\text { pattern; infiltration (with } \\
\text { or without cavitations) } \\
\text { unaltered for }>2 \text { weeks } \\
\text { or worsening despite } \\
\text { nonspecific antibiotic use }\end{array}$ & $\begin{array}{l}\text { Close contact for }< \\
2 \text { years }\end{array}$ & $\begin{array}{c}\text { BCG }>2 \\
\text { years prior } \\
\text { or no BCG } \\
\text { (induration } \geq \\
5 \mathrm{~mm} \text { ) or BCG } \\
<2 \text { years prior } \\
\text { (induration } \geq \\
10 \mathrm{~mm} \text { ) }\end{array}$ & Severe malnutrition \\
\hline Score $=15$ & Score $=15$ & Score $=10$ & Score $=15$ & Score $=5$ \\
\hline $\begin{array}{l}\text { Asymptomatic or } \\
\text { symptomatic for }<2 \\
\text { weeks }\end{array}$ & $\begin{array}{l}\text { Infiltration (with or without } \\
\text { cavitations) for }<2 \text { weeks }\end{array}$ & $\begin{array}{l}\text { No contact or } \\
\text { occasional contact }\end{array}$ & $\begin{array}{l}\text { Induration } 0-4 \\
\mathrm{~mm}\end{array}$ & Normal \\
\hline Score $=0$ & Score $=5$ & & & \\
\hline $\begin{array}{l}\text { Respiratory symptoms } \\
\text { improved spontaneously } \\
\text { or with nonspecific } \\
\text { antibiotic use }\end{array}$ & Normal findings & Score $=0$ & Score $=0$ & Score $=0$ \\
\hline Score $=-10$ & Score $=-5$ & & & \\
\hline
\end{tabular}

TST: tuberculin skin test. ${ }^{a}$ Diagnostic interpretation of the chart: $\geq 40$ points: highly likely; $\geq 30$ and $\leq 39$ points: possible; and $\leq 29$ points: unlikely. Source: Brasil. Ministério da Saúde.(28)

\section{TREATMENT OF ACTIVE TUBERCULOSIS IN CHILDREN AND ADOLESCENTS}

The treatment strategy in Brazil follows what has been proposed by the WHO, separating children under 10 years of age from adolescents and adults. The doses of isoniazid and rifampin have been adjusted according to the WHO standards. ${ }^{(17)}$ The basic treatment regimens for childhood tuberculosis and tuberculous meningitis are detailed in Chart 4 and Chart 5, respectively.

The treatment of MDR-TB (infection with an $M$. tuberculosis strain resistant to at least rifampin and isoniazid) in childhood is still based on the regimens recommended for adults. There has been recent progress toward reducing treatment time in special situations that are relevant to children, mainly due to the recent introduction of the diarylquinoline bedaquiline in such treatment regimens. Therefore, regimens of only 9-12 months can be prescribed in patients who have not previously been treated for MDR-TB. ${ }^{(44)}$ The long-duration regimens in patients with MDR-TB can involve treatment for $\mathbf{2 0}$ months or more, according to the particularities of each case. The factors to be considered in choosing between a short and a long treatment regimen for MDR-TB in childhood can be seen in Chart 6.

In special situations, isoniazid and ethambutol can strengthen the treatment regimen for MDR-TB. ${ }^{(35,45)}$ Another drug that is in the process of being incorporated into treatment regimens for children with MDR-TB is delamanid, which has been shown to be effective in studies of tolerance and pharmacokinetics, although such studies have not included patients with HIV infection, heart disease, severe malnutrition, or other comorbidities. The WHO recommends the use of delamanid in the treatment regimen for MDR-TB in children who are not eligible for the previously mentioned short regimen, especially taking into account that there is no safe position regarding the interaction of bedaquiline and delamanid in the same patient. ${ }^{(46)}$ It has been proposed that the administration of delamanid in childhood constitutes compassionate use. ${ }^{(47,48)}$ However, systematic reviews of bedaquiline and delamanid use in children recommend caution and accurate monitoring of the $\mathrm{Q}_{\mathrm{T}}$ interval corrected with Fridericia's formula. ${ }^{(49-51)}$ Studies of those drugs are scarce, which limits their current usage. ${ }^{(52)}$

In the evaluation of tuberculosis/HIV coinfection in children, it is recommended that all individuals diagnosed with HIV/AIDS and active tuberculosis should start combined antiretroviral therapy (ART), regardless of the clinical form of the tuberculosis and the CD4+ T lymphocyte count. ${ }^{(28,29)}$ It should be borne in mind that the atypical forms of the disease occur in patients with a higher degree of immunodeficiency caused by HIV infection. ${ }^{28,53)}$

During the treatment of tuberculosis/HIV coinfection, when the ART regimen is chosen, it should be taken into consideration that rifampin is a potent inducer of cytochrome P450 and glycoprotein $\mathrm{P}$, which significantly reduces the plasma concentrations of protease inhibitors and non-nucleoside reverse transcriptase inhibitors, because those drugs use the same metabolic pathway. ${ }^{(28)}$

Since 2015 , formulations of anti-tuberculosis drugs in fixed-dose combinations, presented as dissolvable tablets with a pleasant taste, have been available in the following doses: rifampin (75 mg), isoniazid (50 
Chart 4. Basic regimen for the treatment of tuberculosis in children under 10 years of age.

\begin{tabular}{|c|c|c|c|c|c|c|c|c|}
\hline \multirow{2}{*}{$\begin{array}{l}\text { Treatment } \\
\text { phase }\end{array}$} & \multirow[t]{2}{*}{ Drugs } & \multicolumn{7}{|c|}{ Daily dosage, by patient weight } \\
\hline & & $\begin{array}{c}\leq 20 \mathrm{~kg} \\
\mathrm{mg} / \mathrm{kg}\end{array}$ & $\begin{array}{c}21-25 \mathrm{~kg} \\
\mathrm{mg}\end{array}$ & $\begin{array}{c}26-30 \mathrm{~kg} \\
\mathrm{mg}\end{array}$ & $\begin{array}{c}31-35 \mathrm{~kg} \\
\mathrm{mg}\end{array}$ & $\begin{array}{c}36-40 \mathrm{~kg} \\
\mathrm{mg}\end{array}$ & $\begin{array}{c}41-45 \mathrm{~kg} \\
\mathrm{mg}\end{array}$ & $\begin{array}{c}\geq 45 \mathrm{~kg} \\
\mathrm{mg}\end{array}$ \\
\hline \multirow[t]{3}{*}{$2 \mathrm{RHZ}$} & Rifampin & $15(10-20)$ & 300 & 450 & 500 & 600 & 600 & 600 \\
\hline & Isoniazid & $10(7-15)$ & 200 & 300 & 300 & 300 & 300 & 300 \\
\hline & Pyrazinamide & $35(30-40)$ & 750 & 1000 & 1000 & 1500 & 1500 & 2000 \\
\hline \multirow[t]{2}{*}{$4 \mathrm{RH}$} & Rifampin & $15(10-20)$ & 300 & 450 & 500 & 600 & 600 & 600 \\
\hline & Isoniazid & $10(7-15)$ & 200 & 300 & 300 & 300 & 300 & 300 \\
\hline
\end{tabular}

Source: World Health Organization. ${ }^{(17)}$

Chart 5. Basic regimen for the treatment of tuberculous meningitis in children.

\begin{tabular}{|c|c|c|c|c|c|c|c|c|}
\hline \multirow{2}{*}{$\begin{array}{c}\text { Treatment } \\
\text { phase }\end{array}$} & \multirow[t]{2}{*}{ Drugs $^{a}$} & \multicolumn{7}{|c|}{ Daily dosage, by patient weight } \\
\hline & & $\begin{array}{c}\leq 20 \mathrm{~kg} \\
\mathrm{mg} / \mathrm{kg}\end{array}$ & $\begin{array}{c}21-25 \mathrm{~kg} \\
\mathrm{mg}\end{array}$ & $\begin{array}{c}26-30 \mathrm{~kg} \\
\mathrm{mg}\end{array}$ & $\begin{array}{c}31-35 \mathrm{~kg} \\
\mathrm{mg}\end{array}$ & $\begin{array}{c}36-40 \mathrm{~kg} \\
\mathrm{mg}\end{array}$ & $\begin{array}{c}41-45 \mathrm{~kg} \\
\mathrm{mg}\end{array}$ & $\begin{array}{c}\geq 45 \mathrm{~kg} \\
\mathrm{mg}\end{array}$ \\
\hline \multirow[t]{3}{*}{$2 \mathrm{RHZ}$} & Rifampin & $15(10-20)$ & 300 & 450 & 500 & 600 & 600 & 600 \\
\hline & Isoniazid & $10(7-15)$ & 200 & 300 & 300 & 300 & 300 & 300 \\
\hline & Pyrazinamide & $35(30-40)$ & 750 & 1000 & 1000 & 1500 & 1500 & 2000 \\
\hline \multirow[t]{2}{*}{$10 \mathrm{RH}$} & Rifampin & $15(10-20)$ & 300 & 450 & 500 & 600 & 600 & 600 \\
\hline & Isoniazid & $10(7-15)$ & 200 & 300 & 300 & 300 & 300 & 300 \\
\hline
\end{tabular}

Source: World Health Organization.(17) a During the treatment of tuberculous meningitis, a corticosteroid can be added to the anti-tuberculosis regimen: oral prednisone $(1-2 \mathrm{mg} / \mathrm{kg}$ daily) for four weeks or, in severe cases, intravenous dexamethasone (0.3-0.4 mg/kg daily) for 4-8 weeks, with gradual dose reductions over the subsequent 4 weeks.

Chart 6. Factors to consider when choosing the treatment regimen for children with multidrug-resistant tuberculosis.

\begin{tabular}{|c|c|c|}
\hline \multicolumn{3}{|c|}{$\begin{array}{l}\text { - Confirmed susceptibility to or presumed efficacy of all drugs of the short MDR-TB regimen (isoniazid resistance } \\
\text { excepted) } \\
\text { - No exposure to the second-line MDR-TB regimen for > } 1 \text { month } \\
\text { - No intolerance to any drug in the short non-toxic MDR-TB regimen (i.e., drug interactions) } \\
\text { - Pregnancy excluded } \\
\text { - Pulmonary disease only } \\
\text { - All drugs in the short MDR-TB regimen are available for the program }\end{array}$} \\
\hline $\begin{array}{c}\downarrow \\
\text { YES } \\
\downarrow\end{array}$ & & $\begin{array}{c}\downarrow \\
\text { NO } \\
\downarrow\end{array}$ \\
\hline Short MDR-TB regimen & $\begin{array}{c}\text { Regimen failure, drug intolerance, } \\
\text { return after interruption for }>2 \\
\text { months, emergence of an exclusion } \\
\text { criterion } \rightarrow\end{array}$ & $\begin{array}{c}\text { Longer (individualized) MDR-TB } \\
\text { regimen }\end{array}$ \\
\hline
\end{tabular}

MDR-TB: multidrug-resistant tuberculosis. Source: Grzemska M. ${ }^{(9)}$

$\mathrm{mg})$, and pyrazinamide (150 $\mathrm{mg}$ ) for the intensive phase; and rifampin (75 mg) and isoniazid (75 mg) for the maintenance phase. Although those formulations are not yet available in Brazil, there are ongoing negotiations to acquire them. There are as yet no second-line drugs available in formulations suitable for children. Therefore, the treatment of MDR-TB still presents obstacles related to the administration of many drugs that need to be adapted to administration in pediatric patients, which clearly has a negative impact on adherence. ${ }^{(54,55)}$

\section{TUBERCULOSIS PREVENTION IN CHILDREN}

The health interventions currently available for tuberculosis prevention which relate specifically to children are LTBI treatment and BCG vaccination. LTBI is defined as a state of persistent immune response to exposure to $M$. tuberculosis without clinical or radiological evidence of active tuberculosis. ${ }^{(56)}$ Adults and children who are in contact with smear-positive PTB patients are at a higher risk of LTBI and of progression from LTBI to active disease, as well as a higher incidence of active tuberculosis. ${ }^{(57-60)}$ The pharmacological treatment of LTBI is the main intervention capable of preventing the progression to active tuberculosis in such individuals. (2)

Children, in particular those under 5 years of age, represent a group for which there is clear evidence of the benefits of testing for and treating LTBI. ${ }^{(58-60)}$ The $\mathrm{WHO}^{(59)}$ the International Union against Tuberculosis and Lung Disease, ${ }^{(19)}$ and the International Standards for Tuberculosis Care, ${ }^{(61)}$ as well as the main NorthAmerican and European guidelines, ${ }^{(62-65)}$ are unanimous in recommending that, after active tuberculosis has been excluded, LTBI be treated in two high-risk groups: children under 5 years of age and people living with HIV who have been exposed to cases of bacteriologically 
confirmed PTB. Screening children under 5 years of age for active tuberculosis and LTBI is a strategy recommended by the $\mathrm{WHO}$, even in countries with limited resources. ${ }^{(57,59)}$

The Brazilian National Tuberculosis Program guidelines recommend that the investigation and, if necessary, the treatment of LTBI in children under 5 years of age who have been in contact with smear-positive PTB cases be prioritized. (28) However, only $44.9 \%$ of such contacts were screened in 2015 in the country as a whole; in the states of Amapá and Rio de Janeiro, that proportion was only $22.3 \%$ and $22.1 \%$, respectively, in that same year. ${ }^{(3)}$

In 2016, there were, worldwide, approximately 1.3 million children under 5 years of age who were close contacts of bacteriologically confirmed PTB cases and were therefore eligible for preventive tuberculosis treatment. Although the number of children in this age group who reportedly started the treatment for LTBI increased by $85 \%$ between 2015 and 2016, it still represents only $13 \%$ of the children who are eligible to receive treatment. ${ }^{(1)}$

Administration of the treatment for LTBI in children under 5 years of age who are contacts of smear-positive PTB cases (some guidelines use the term "cases of contagious tuberculosis", also including cases of laryngeal tuberculosis) is recommended whether or not there has been confirmation of LTBI. ${ }^{(56,57,61)}$ As in adults, the diagnosis of LTBI in children is based on the results of a TST performed by the Mantoux method. The interpretation of those results (skin induration measured in millimeters) varies according to the degree of exposure to the index case and to the BCG immunization status. In Brazil, children and adolescents who are household contacts of PTB cases and have not been vaccinated with BCG or were vaccinated more than 2 years prior are considered positive if their response to a TST is a skin induration of at least $5 \mathrm{~mm}$. In the case of those vaccinated with BCG less than 2 years prior, the cut-off induration for positivity is $10 \mathrm{~mm}$. Contacts initially showing negative TST results should repeat the test after 8 weeks. (28)

Interferon-gamma release assays (IGRAs) have lower sensitivity in children under 2 years of age and in those who are immunosuppressed; IGRAs are not typically recommended for use in this age group. $(17,65,66)$ The frequency of indeterminate test results among such children is apparently higher with the QuantiFERON-TB Gold In-Tube test than with the T-SPOT.TB test. For older children, the sensitivity and specificity of the QuantiFERON-TB Gold In-Tube test and the T-SPOT.TB test are comparable to those reported for their use in adults. However, in comparison with TSTs, IGRAs are more expensive and require laboratory support that is more sophisticated, therefore not being indicated as a substitute for TST in regions where resources are limited. ${ }^{(17,56)}$

The recommended treatment regimens for LTBI are as follows ${ }^{(56,62)}$ : isoniazid daily for 6 months or 9 months (the 9-month regimen is the only one that the U.S. Centers for Disease Control and Prevention recommend for use in children); isoniazid plus rifampin daily for 3-4 months; rifampin daily for 3-4 months; and isoniazid plus rifapentine weekly for 3 months (not recommended for children under 2 years of age or for HIV-infected patients on ART).

The effectiveness of treating LTBI with isoniazid for 6-12 months (ideally, for 9 months) is estimated to be $60-90 \%$, with no significant differences in the level of protection among treatments of different durations. ${ }^{(67)}$ A recent review showed that prophylaxis with isoniazid given to HIV-infected children in Africa reduces the risk of active tuberculosis and death among those who are not on ART, although there was no clearly observed benefit for the children who are on ART. ${ }^{(68)}$ The use of the 6-month regimen of isoniazid (5-10 $\mathrm{mg} / \mathrm{kg}$ daily, up to a maximum of $300 \mathrm{mg} /$ day) is the strategy recommended by the Brazilian National Tuberculosis Program, and the regimen is generally well tolerated by children and adolescents. (28) For adults and children who are contacts of MDR-TB cases, there are as yet no regimens for preventive treatment based on efficacy studies, although the execution of such studies is considered a priority by the scientific community. The combination of at least two drugs (at least one of which should be a bactericide) is the regimen recommended by experts. ${ }^{(35,69)}$

One of the priority indicators of the End TB Strategy is the preventive treatment of $\geq 90 \%$ of HIV-infected individuals and children who are contacts of PTB cases. ${ }^{(4)}$ However, to achieve that objective, it will be necessary to increase the capacity of programs to investigate contacts and to offer preventive therapy. Several barriers to the preventive treatment in children have been identified, such as the inability to exclude active tuberculosis, the fear of creating resistance to tuberculosis drugs, the poor adherence to longduration treatment regimens, the low socioeconomic level of some families, and poor adherence to active tuberculosis treatment by index cases. ${ }^{(14,70)}$ Unless those barriers can be overcome, the indicators concerning the investigation of contacts and the completion of preventive tuberculosis treatment with isoniazid in children will be far from what is expected.

For more than 100 years, the BCG vaccine has been available for the primary prevention of tuberculosis in children. Although the vaccine prevents $60-90 \%$ of cases of the severe forms of active tuberculosis in children (disseminated forms and tuberculosis meningitis), it is not efficacious in the prevention of the disease in adults. ${ }^{(17)}$ In Brazil, there is a high level of BCG immunization coverage. ${ }^{(3,28)}$ However, that has not had a significant impact on the number of cases of PTB or the less severe forms of extrapulmonary tuberculosis among children infected by $M$. tuberculosis after vaccination. The slow decline in the incidence of tuberculosis observed worldwide in recent decades underscores the need for a more effective vaccine against tuberculosis, one that would provide protection 
against all forms of tuberculosis in different age groups. In 2017, there were 12 new tuberculosis vaccines being tested in phase I, II, or III trials. ${ }^{(1)}$

\section{FINAL COMMENTS}

Children represent the most fragile link among the complex mechanisms currently involved in the control of tuberculosis. In order to achieve the ambitious goals outlined in the End TB Strategy, concerted efforts are required from the various sectors of society. Priority should be given to measures that address the peculiarities of tuberculosis in childhood: ensuring the early identification (through contact screening) and treatment of active tuberculosis and LTBI in children; using methods that are more sensitive and less invasive for the diagnosis of extrapulmonary tuberculosis and of tuberculosis in patients who produce paucibacillary samples; making child-friendly anti-tuberculosis drugs more widely available; developing tuberculosis vaccines that are more effective; and formulating new drugs for resistant forms of tuberculosis that have low toxicity in children. Adequate financial resources and political will are essential if these goals are to be met and tuberculosis is finally to be removed from the list of the leading causes of death among children worldwide.

\section{ACKNOWLEDGMENTS}

The paper is part of the European Respiratory Society/ Latin-American Thoracic Association and European Respiratory Society/Brazilian Thoracic Association collaborative projects.

\section{REFERENCES}

1. World Health Organization [homepage on the Internet]. Geneva: World Health Organization; [cited 2017 Nov 27]. Global tuberculosis report 2017. [Adobe Acrobat document, 262p.]. Available from: http://apps.who.int/iris/bitstream/10665/259366/1/9789241565516eng.pdf?ua $=1$

2. World Health Organization [homepage on the Internet]. Geneva: World Health Organization; [cited 2017 Nov 27]. Global tuberculosis report 2016. [Adobe Acrobat document, 214p.]. Available from: http:// apps.who.int/medicinedocs/documents/s23098en/s23098en.pdf

3. Brasil. Ministério da Saúde. Secretaria de Vigilância em Saúde. Departamento de Vigilância das Doenças Transmissíveis [homepage on the Internet]. Brasília: Ministério da Saúde; [cited 2017 Feb 24]. Brasil Livre da Tuberculose. Plano nacional pelo fim da tuberculose como problema de saúde pública; 1st ed; 2017. [Adobe Acrobat document, 40p.]. Available from http://portalarquivos.saude.gov.br/ images/pdf/2017/fevereiro/24/Plano-Nacional-Tuberculose.pdf

4. World Health Organization [homepage on the Internet]. Geneva: World Health Organization; [cited 2017 Mar 24]. The End TB Strategy. [Adobe Acrobat document, 20p.]. Available from: http://www.who. int/tb/End_TB_brochure.pdf?ua=

5. Lönnroth K, Migliori GB, Abubakar I, D'Ambrosio L, de Vries G, Die $R$, et al. Towards tuberculosis elimination: an action framework for low-incidence countries. Eur Respir J. 2015;45(4):928-52. https://doi. org/10.1183/09031936.00214014

6. Rendon A, Fuentes Z, Torres-Duque CA, Granado MD, Victoria $J$, Duarte $R$, et al. Roadmap for tuberculosis elimination in Latin American and Caribbean countries: a strategic alliance. Eur Respir J. 2016;48(5):1282-1287. https://doi.org/10.1183/13993003.01549 2016

7. World Health Organization [homepage on the Internet]. Geneva: World Health Organization; [cited 2017 Feb 24]. Roadmap for childhood tuberculosis: towards zero deaths. [Adobe Acrobat document, 44p.]. Available from: http://apps.who.int/iris/ bitstream/10665/89506/1/9789241506137_eng.pdf

8. Carvalho AC, DeRiemer K, Nunes ZB, Martins M, Comelli M Marinoni $A$, et al. Transmission of Mycobacterium tuberculosis to contacts of HIV-infected tuberculosis patients. Am J Respir Crit Care Med. 2001;164(12):2166-71. https://doi.org/10.1164/ ajrccm.164.12.2103078

9. Grzemska M. Updated WHO treatment guidelines and the use of new drugs in children. Resid Pediatr. 2017;7(Suppl 1):7-10. https:// doi.org/10.25060/residpediatr-2017.v7s1-03

10. Seddon JA, Shingadia D. Epidemiology and disease burden of tuberculosis in children: a global perspective. Infect Drug Resist. 2014;7:153-65.

11. Dodd PJ, Gardiner E, Coghlan R, Seddon JA. Burden of childhood tuberculosis in 22 high-burden countries: a mathematical modelling study. Lancet Glob Health. 2014;2(8):e453-9. https://doi.org/10.1016/ S2214-109X(14)70245-1

12. Jenkins $H E$, Yuen $C M$, Rodriguez $C A$, Nathavitharana $R R$ McLaughlin MM, Donald $P$, et al. Mortality in children diagnosed

with tuberculosis: a systematic review and meta-analysis. Lancet Infect Dis. 2017;17(3):285-295. https://doi.org/10.1016/S1473 3099(16)30474-1

13. Graham SM, Sismanidis C, Menzies HJ, Mariais BJ, Detjen AK, Black RE. Importance of tuberculosis control to address child survival. Lancet. 2014;383(9928):1605-7. https://doi.org/10.1016/S01406736(14)60420-7

14. Marais BJ. Improving access to tuberculosis preventive therapy and treatment for children. Int J Infect Dis. 2017;56:122-125. https://doi org/10.1016/j.ijid.2016.12.015

15. Brasil. Ministério da Saúde. Secretaria de Políticas de Saúde. Departamento de Atenção Básica. Manual técnico para o controle da tuberculose. Brasília: Ministério da Saúde; 2002.

16. Sant'Anna CC. Diagnóstico da tuberculose na infância e na adolescência. Pulmão RJ. 2012; 21(1):60-64

17. World Health Organization [homepage on the Internet]. Geneva: World Health Organization; [cited 2017 Dec 2]. Guidance for national tuberculosis programmes on the management of tuberculosis in children. 2nd ed. [Adobe Acrobat document, 146p.]. Available from: http://apps.who.int/medicinedocs/documents/s21535en/s21535en. pdf

18. Newton SM, Brent AJ, Anderson S, Whittaker E, Kampmann B Paediatric tuberculosis. Lancet Infect Dis. 2008;8(8):498-510. https:// doi.org/10.1016/S1473-3099(08)70182-8

19. The Union -- International Union against Tuberculosis and Lung Diseases [homepage on the Internet]. Paris: The Union; [cited 2017 Nov 29]. The Union's desk guide for diagnosis and management of TB in children. 3rd ed; 2016. [Adobe Acrobat document, 40p.]. Available from: https://www.theunion.org/what-we-do/publications/ english/2016_Desk-guide_Africa_Web.pdf

20. Luzzati R, Migliori GB, Zignol M, Cirillo DM, Maschio M, Tominz R Children under 5 years are at risk for tuberculosis after occasional contact with highly contagious patients: outbreak from a smearpositive healthcare worker. Eur Respir J. 2017;50(5). pii: 1701414 https://doi.org/10.1183/13993003.01414-2017

21. Shingadia D, Novelli V. Diagnosis and treatment of tuberculosis in children. Lancet Infect Dis. 2003;3(10):624-32. https://doi. org/10.1016/S1473-3099(03)00771-0

22. Marais BJ, Gie RP, Schaaf HS, Hesseling AC, Obihara CC, Nelson LJ, et al. The clinical epidemiology of childhood pulmonary tuberculosis: a critical review of literature from the pre-chemotherapy era. Int $J$ Tuberc Lung Dis. 2004;8(3):278-85.

23. Donald PR. The North American contribution to our knowledge of childhood tuberculosis and its epidemiology. Int J Tuberc Lung Dis. 2014;18(8):890-8. https://doi.org/10.5588/ijtld.13.0915

24. Marais BJ, Gie RP, Schaaf HS, Hesseling AC, Obihara CC, Starke $\mathrm{JJ}$, et al. The natural history of childhood intra-thoracic tuberculosis: a critical review of literature from the pre-chemotherapy era. Int $J$ Tuberc Lung Dis. 2004;8(4):392-402

25. Marais BJ, Gie RP, Obihara CC, Hesseling AC, Schaaf HS, Beyers $\mathrm{N}$. Well defined symptoms are of value in the diagnosis of childhood 
pulmonary tuberculosis. Arch Dis Child. 2005;90(11):1162-5. https:// doi.org/10.1136/adc.2004.070797

26. Sant'Anna C, March MF, Barreto M, Pereira S, Schmidt C. Pulmonary tuberculosis in adolescents: radiographic features. Int J Tuberc Lung Dis. 2009;13(12):1566-8.

27. Marques HHS, Sant'Anna C. Tuberculose. In: Rodrigues JC, Adde FV, Silva LVRF. Doenças Respiratórias. São Paulo: Manole; 2008.

28. Brasil. Ministério da Saúde. Secretaria de Vigilância em Saúde. Departamento de Vigilância Epidemiológica. Manual de recomendações para o controle da tuberculose no Brasil. Brasília: Ministério da Saúde; 2011

29. Brasil. Ministério da Saúde. Secretaria de Vigilância em Saúde. Programa Nacional de DST e Aids. Protocolo clínico e diretrizes terapêuticas para manejo da infecção pelo HIV em crianças e adolescentes. Guia de Tratamento. Brasília: Ministério da Saúde 2017

30. World Health Organization [homepage on the Internet]. Geneva: World Health Organization; [cited 2017 Dec 12]. Guidelines for intensified tuberculosis case-finding and isoniazid preventive therapy for people living with HIV in resource-constrained settings. [Adobe Acrobat document, 52p.]. Available from: http http://apps.who.int/ iris/bitstream/10665/44472/1/9789241500708_eng.pdf

31. Gie R. Diagnostic Atlas of Intrathoracic Tuberculosis in Children. Paris: International Union Against Tuberculosis and Lung Disease: 2003

32. Zar HJ, Hanslo D, Apolles P, Swingler G, Hussey G. Induced sputum versus gastric lavage for microbiological confirmation of pulmonary tuberculosis in infants and young children: a prospective study. Lancet. 2005;365(9454):130-4. https://doi.org/10.1016/S0140$6736(05) 17702-2$

33. Planting NS, Visser GL, Nicol MP, Workman L, Isaacs W, Zar HJ Safety and efficacy of induced sputum in young children hospitalised with suspected pulmonary tuberculosis. Int J Tuberc Lung Dis. 2014;18(1):8-12. https://doi.org/10.5588/ijtld.13.0132

34. Nicol MP, Whitelaw A, Stevens W. Using Xpert MTB/RIF. Cur Resp Med Rev. 2013:9:187-192. https://doi.org/10.2174/157339 $8 \times 113099990015$

35. World Health Organization [homepage on the Internet]. Geneva: World Health Organization; [updated 2016 Oct; cited 2017 Dec 14] WHO treatment guidelines for drug-resistant tuberculosis-2016 update. [Adobe Acrobat document, 64p.]. Available from: http:/ apps.who.int/iris/bitstream/10665/250125/1/9789241549639-eng. pdf?ua $=1$

36. World Health Organization [homepage on the Internet]. Geneva: World Health Organization; lupdated 2016 Oct; cited 2017 Dec 14]. Automated real-time nucleic acid amplification technology for rapid and simultaneous detection of tuberculosis and rifampicin resistance: Xpert MTB/RIF assay for the diagnosis of pulmonary and extrapulmonary TB in adults and children. Policy update 2013 [Adobe Acrobat document, 97p.]. Available from http://apps.who.int/ iris/bitstream/10665/112472/1/9789241506335_eng.pdf?ua=1

37. Sieiro TLA, Aurílio RB, Soares ECC, Chiang SS, Sant'Anna CC. The role of the Xpert MTB/RIF assay among adolescents suspected of pulmonary tuberculosis in Rio de Janeiro, Brazil. Rev Soc Bras Med Trop. In press 2018

38. Sant'Anna C, Orfaliais CT, March Mde F, Conde MB. Evaluation of a proposed diagnostic scoring system for pulmonary tuberculosis in Brazilian children. Int J Tuberc Lung Dis. 2006;10(4):463-5.

39. Pedrozo C, Sant'Anna C, de Fatima March M, Lucena S. Clinical scoring system for paediatric tuberculosis in HIV-infected and non-infected children in Rio de Janeiro. Int $J$ Tuberc Lung Dis. 2009;13(3):413-5

40. Edwards DJ, Kitetele F, Van Rie A. Agreement between clinical scoring systems used for the diagnosis of pediatric tuberculosis in the HIV era. Int J Tuberc Lung Dis. 2007;11(3):263-9.

41. Pearce EC, Woodward JF, Nyandiko WM, Vreeman RC, Ayaya SO. A systematic review of clinical diagnostic systems used in the diagnosis of tuberculosis in children. AIDS Res Trat 2012;2012:401896. https:// doi.org/10.1155/2012/401896

42. David SG, Lovero KL, Pombo March MFB, Abreu TG, Ruffino Netto A, Kritski AL. A comparison of tuberculosis diagnostic systems in a retrospective cohort of HIV-infected children in Rio de Janeiro, Brazil. Int J Infect Dis. 2017;59:150-155. https://doi.org/10.1016/i. ijid.2017.01.038

43. Nansumba M, Kumbakumba E, Orikiriza $P$, Muller $Y$, Nackers F, Debeaudrap P, et al. Detection Yield and Tolerability of String
Test for Diagnosis of Childhood Intrathoracic Tuberculosis Pediatr Infect Dis J. 2016;35(2):146-51. https://doi.org/10.1097/ INF.0000000000000956

44. Falzon D, Schünemann HJ, Harausz E, González-Angulo L, Lienhard $C$, Jaramillo $E$, et al. World Health Organization treatment guidelines for drug-resistant tuberculosis, 2016 update. Eur Respir J. 2017;49(3) pii: 1602308. https://doi.org/10.1183/13993003.02308-2016

45. Pai M, Behr MA, Dowdy D, Dheda K, Divangahi M, Boehme CC et al. Tuberculosis. Nat Rev Dis Primers. 2016:2:16076. https://doi. org/10.1038/nrdp.2016.76

46. World Health Organization. The use of delamanid in the treatment of multidrug-resistant tuberculosis in children and adolescents: interim policy guidance. Geneva: World Health Organization; 2016.

47. Tadolini M, Garcia-Prats AJ, D'Ambrosio L, Hewison C, Centis $\mathrm{R}$, Schaaf HS, et al. Compassionate use of new drugs in children and adolescents with multidrug-resistant and extensively drugresistant tuberculosis: early experiences and challenges. Eur Resp J. 2016;48(3):938-943. https://doi.org/10.1183/13993003.00705-2016

48. Esposito S, Bosis S, Tadolini M, Bianchini S, Migliori GB, Princip N. Efficacy, safety, and tolerability of a 24-month treatment regimen including delamanid in a child with extensively drugresistant tuberculosis: A case report and review of the literature. Medicine (Baltimore). 2016;95(46):e5347. https://doi.org/10.1097/ MD.00000000000005347

49. Pontali E, Sotgiu G, D’Ambrosio L, Centis R, Migliori GB. Bedaquiline and multidrug-resistant tuberculosis: a systematic and critica analysis of the evidence. Eur Respir J. 2016;47(2):394-402. https:// doi.org/10.1183/13993003.01891-2015

50. Pontali E, D'Ambrosio L, Centis R, Sotgiu G, Migliori GB. Multidrugresistant tuberculosis and beyond: an updated analysis of the curren evidence on bedaquiline. Eur Respir J. 2017:49(3). pii: 1700146. https://doi.org/10.1183/13993003.00146-2017

51. Pontali E, Sotgiu G, Tiberi S, D'Ambrosio L, Centis R, Migliori GB. Cardiac safety of bedaquiline: a systematic and critical analysis of the evidence. Eur Respir J. 2017;50(5). pii: 1701462. https://doi. org/10.1183/13993003.01462-2017

52. D'Ambrosio L, Centis R, Tiberi S, Tadolini M, Dalcolmo M, Rendon A et al. Delamanid and bedaquiline to treat multidrug-extensively drugresistant tuberculosis in children: a systematic review. J. Thorac Dis 2017:9(7):2093-2101. https://doi.org/10.21037/itd.2017.06.16

53. Brasil. Ministério da Saúde. Secretaria-Executiva. Recomendaçōes para o manejo da coinfecção TB-HIV em serviços de atenção especializada a pessoas vivendo com HIV/AIDS. Brasília: Ministério da Saúde; 2013.

54. Brands A, Volz A. Childhood tuberculosis in Americas: challenges, opportunities and steps to be taken. Resid Pediat. 2016;6(1):11-15. https://doi.org/10.25060/residpediatr-2016.v6n1-02

55. TB ALLIANCE [homepage on the Internet]. New York City: TB ALLIANCE; [cited 2017 Nov 30]. Child-friendly medicines; [about 11 screens]. Available from: https://www.tballiance.org/child-friendly medicines

56. World Health Organization [homepage on the Internet]. Geneva: World Health Organization; [cited 2017 Feb 24]. Guidelines on the management of latent tuberculosis infection. [Adobe Acrobat document, 38p.l. Available from: http://apps.who.int/iris/ bitstream/10665/136471/1/9789241548908_eng.pdf?ua=1\&ua=1

57. World Health Organization [homepage on the Internet]. Geneva: World Health Organization; [cited 2017 Dec 10] Recommendations for investigating contacts of persons with infectious tuberculosis in low- and middle-income countries. [Adobe Acrobat document, 70p.]. Available from: http://apps.who.int/iris/ bitstream/10665/77741/1/9789241504492_eng.pd

58. Fox GJ, Barry SE, Britton WJ, Marks GB. Contact investigation for tuberculosis: a systematic review and meta-analysis. Eur Respir J. 2013;41(1):140-56. https://doi.org/10.1183/09031936.00070812

59. Getahun H, Matteelli A, Abubakar I, Aziz MA, Baddeley A, Barreira D, et al. Management of latent Mycobacterium tuberculosis infection: WHO guidelines for low tuberculosis burden countries. Eur Respir J. 2015;46(6):1563-76. https://doi.org/10.1183/13993003.01245-2015

60. Comstock GW, Livesay VT, Woolpert SF. The prognosis of a positive tuberculin reaction in childhood and adolescence. Am J Epidemiol. 1974;99(2):131-8. $\quad$ https://doi.org/10.1093/oxfordjournals.aje. a121593

61. World Health Organization [homepage on the Internet]. Geneva: World Health Organization; [cited 2017 Nov 29]. TB CARE International Standards for Tuberculosis Care, 3rd ed; 2014. [Adobe 
Acrobat document, 92p.]. Available from: http://www.who.int/tb/ publications/ISTC_3rdEd.pdf?ua=1

62. Centers for Disease Control and Prevention - CDC [homepage in the internet]. Atlanta (GA): CDC; [cited 2017 Nov 29]. Latent Tuberculosis Infection: A Guide for Primary Health Care Providers. [Adobe Acrobat document, 40p.]. Available from: https://www.cdc. gov/tb/publications/tbi/pdf/TargetedLTBI.pdf

63. Public Health Agency of Canada. Centre for Communicable Diseases and Infection Control [homepage on the Internet]. Ottawa: Public Health Agency of Canada; [cited 2017 Nov 29]. Canadian Tuberculosis Standards. 7th ed. 2014. [Adobe Acrobat document, 468p.]. Available from: http://publications.gc.ca/collections/collection_2014/aspcphac/HP40-18-2014-eng.pdf

64. Migliori GB, Zellweger JP, Abubakar I, Ibraim E, Caminero JA, De Vries $\mathrm{G}$, et al. European union standards for tuberculosis care. Eur Respir J. 2012;39(4):807-19. https://doi.org/10.1183/09031936.00203811

65. Bergamini BM, Losi M, Vaienti F, D'Amico R, Meccugni B, Meacci $\mathrm{M}$, et al. Performance of commercial blood tests for the diagnosis of latent tuberculosis infection in children and adolescents. Pediatrics. 2009;123(3):e419-24. https://doi.org/10.1542/peds.2008-1722

66. Carvalho AC, Schumacher RF, Bigoni S, Soncini E, Notarangelo L,
Apostoli $A$, et al. Contact investigation based on serial interferongamma release assays (IGRA) in children from the hematologyoncology ward after exposure to a patient with pulmonary tuberculosis. Infection. 2013;41(4):827-31. https://doi.org/10.1007/ s15010-013-0450-y

67. Smieja M, Marchetti C, Cook D, Smaill FM. Isoniazid for preventing tuberculosis in non-HIV infected persons. Cochrane Database Syst Rev. 2000; (2):CD001363.

68. Zunza M, Gray DM, Young T, Cotton M, Zar HJ. Isoniazid for preventing tuberculosis in HIV-infected children. Cochrane Database Syst Rev. 2017;8:CD006418. https://doi.org/10.1002/14651858. CD006418.pub3

69. Lange C, Abubakar I, Alffenaar JW, Bothamley G, Caminero $J A$, Carvalho AC, et al. Management of patients with multidrugresistant/extensively drug-resistant tuberculosis in Europe: a TBNET consensus statement. Eur Respir J. 2014;44(1):23-63. https://doi. org/10.1183/09031936.00188313

70. Mendonça AM, Kritski AL, Land MG, Sant'Anna CC. Abandonment of Treatment for Latent Tuberculosis Infection and Socioeconomic Factors in Children and Adolescents: Rio De Janeiro, Brazil. PLoS One. 2016;11(5):e0154843. https://doi.org/10.1371/journal. pone. 0154843 